\author{
September 13, 1957.
}

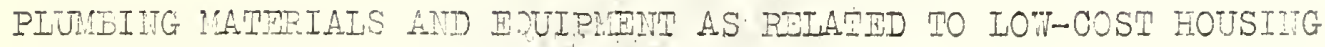

$$
\text { I. - General }
$$

Circuler Lettef, 502, outlining the objectives, piocecure and scone of the Eureau program of research on builaing naterials with resnect to their use in low-cost housing, enmerates plumbing as one of the elemonts of cost of housing to be included in the reserircin. The plumbing systen of a house, as usually defined, includes: the water suprly and distributing pires from a sourse of surply (usually the street water main); the plumbing fixtures, traps and fitines; the soil, waste and vert pipes within the house; and the house drain and house sewer from the soil and waste pines in the house to a place of sewak"e disposal (usual.y the street sewer). Intirely asice from the variation in lind and cost of materials available for use in installing a plurning system, the plumbing is probebly more susceptiblo to variation in cost than iny otier single element of the house, because of the creater valiation in quontity of material and the labor required to irstall a given uilt of ecuimment. The costs of bringing in the witer suply and curring the drainege to the strect sewcr are almost entirely inderendent of the size and quality of the house. The costs of distributing the water suply to the units of equipment (brth roon, pitchen sirk, lundry trays, etc.) and of carrying the drains rrom trese units to the house cran are also itens of cost berring no direct rem lation to the quality of the house.

In riew of these facts, it appears that there is an opportiutty for é considerable rouction in costs, entirely aside from the uult ity of materials cmioyod, throug a careful planning of the plombirg system by the archivect, owner or builder, in resoect to the location of the diferent units of equipment (Doth rooms, etc.), the cirrinsunent of the fixtures within a group as to compctiness and s propor relation to bearing partitions and floor joists. The restaich in lurroing will be directed towara collectire the date needed for tis planing and arrangiug those data in a form for vose in such planing.

\section{Present status of information}

Although mucin of the planning sugestied covld be lone on tire Dasis of mesont informetion, full advantage of the oppoturities fol economg are not being taken. This is party beckuso the available data are not in a form to incicate cicarly the minimu limits to wich compactness of arrangement and mininum size of drains can be salely caried; partly because of differences in the specific reririenents or the plumbing codes in diferent localities (suates and cities) in some cases, and because of uneconoucal and unnecasary requirements of the local code in other cases; and partly because the plumber. is pumitted to follow a local custom or use his ow judgment regaraing the arrangument and sizes of wator and orain pipes insulled, irrespective of the minimm requirements of the plumbing code applying or the actual needs as shom 
by sciontific detu.

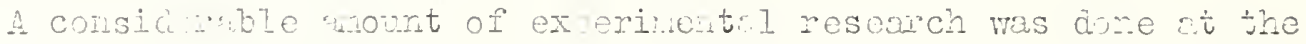
Burew. in 1921 and 1922 in respect to the minimur requirements in plub ng for one an tmatom dmellings. These data were uilized by tie Subconitte on Plumbing or the Jeprutnent of Comonce Bulaing Core Conwitce in formulating "Recommond Kinimu Recuirements for Plumbing." I

Mi:o; Pecomended Hinimum Feouirments for Plunbing hove beon

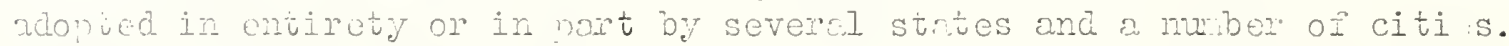

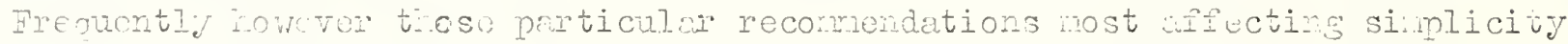

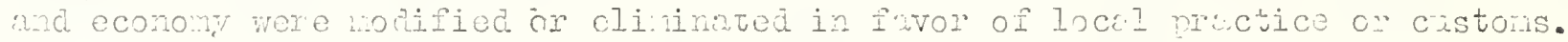

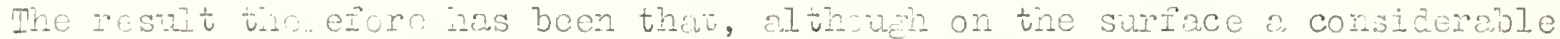

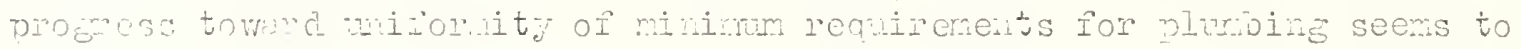
huve beon ade, compritively litile imorovont has buen nade in purbing Div ctices.

There ale als other problems in pluning that aflect the cost of

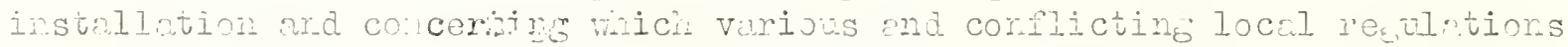
are belap uroped, for exmple healti- regulations protining to cins-connections in puning sjstens. It is extrenely imortant fron tie stancipoint oI cost tict the rentations pplying to such maters should be as uniform

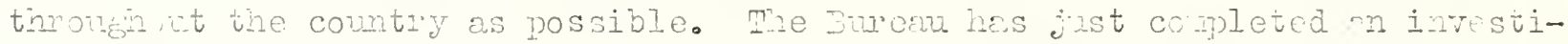

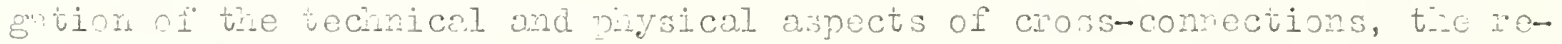

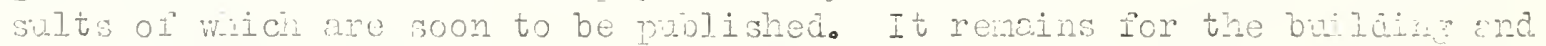

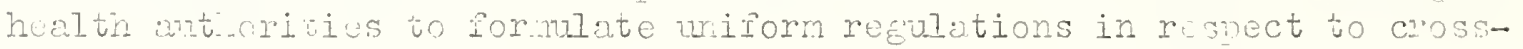
connections before this project cun be satisfactorily compleced.

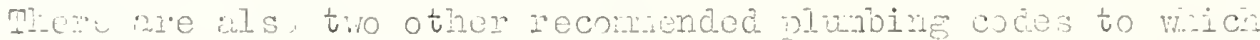

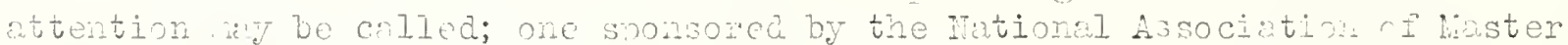

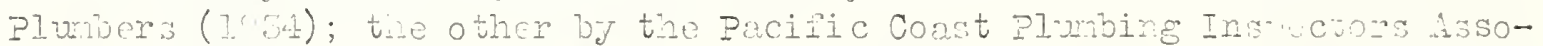
ciftion (1:5). So far as we cure ble to l.am, neithur of tro:o codes has

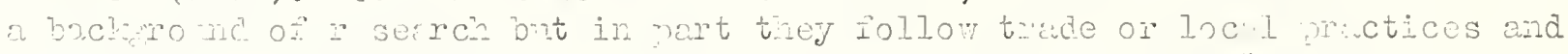

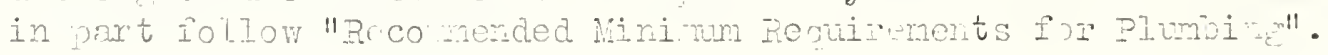

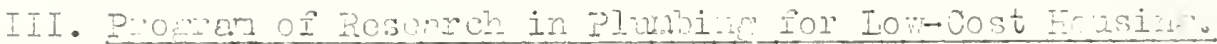

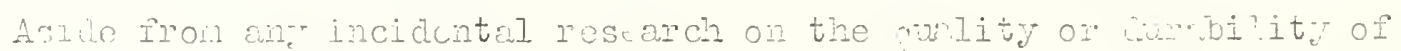

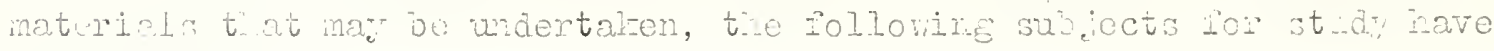
been \& poroved:

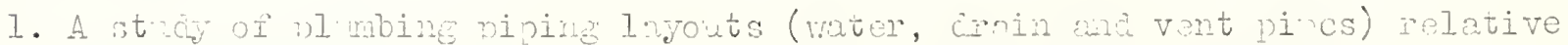

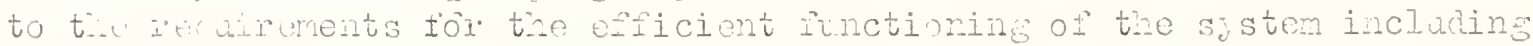

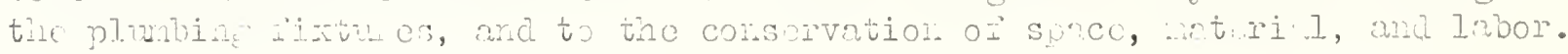

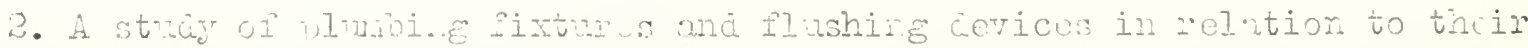

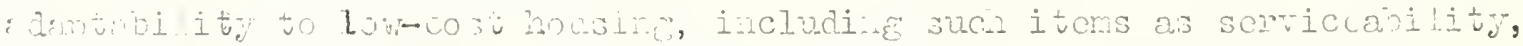

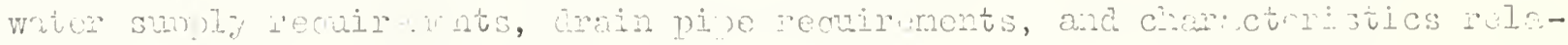
tive to pise, baci-sipione, otc.

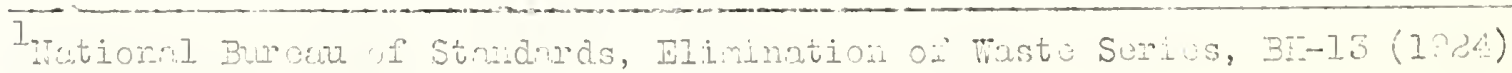

(rovisca 102-10\%.) 
3. Complation of the data from 1 ond 2 in a form so as to cliarly incicate and illustrate the nost econonical, sorvicable layout wit.. a aivon matricl.

4. Prevention of becl-flow into weter surply systems.

A. Specifications coverine construction of sustem or devices regired for the pevention of bach-row into water supl systems.

B. Developient of a strudnd comince tust and test procedire for devices specificd under $(A)$. 
